
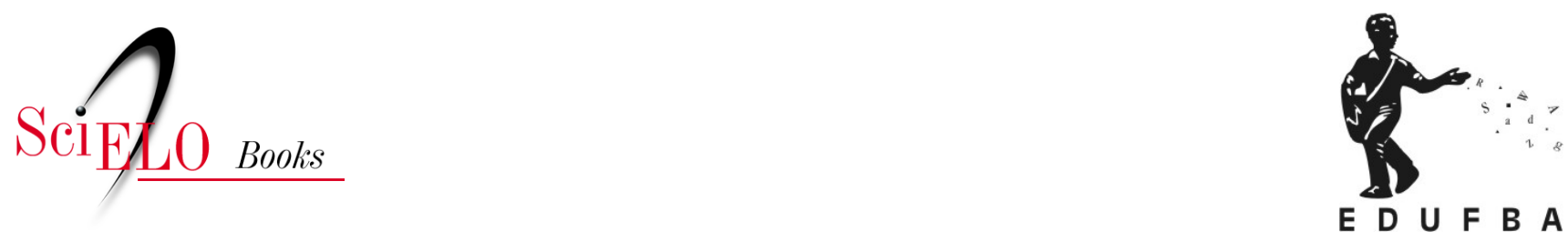

\title{
Reflexões \\ Jovens cientistas criadores de cultura
}

\author{
Nelson De Luca Pretto
}

PRETTO, N.D.L. Jovens cientistas criadores de cultura. In: Educações, culturas e hackers: escritos e reflexões [online]. Salvador: EDUFBA, 2017, pp. 163-165. ISBN: 978-85-232-2019-8.

https://doi.org/10.7476/9788523220198.0041.

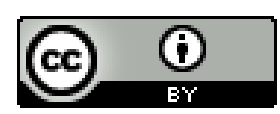

All the contents of this work, except where otherwise noted, is licensed under a Creative Commons Attribution $\underline{4.0 \text { International license. }}$

Todo o conteúdo deste trabalho, exceto quando houver ressalva, é publicado sob a licença Creative Commons Atribição 4.0.

Todo el contenido de esta obra, excepto donde se indique lo contrario, está bajo licencia de la licencia Creative Commons Reconocimento 4.0. 
rente, um processo de burocratização e de contingenciamento financeiro e, o pior, com uma enorme dificuldade na liberação dos recursos aprovados, o que praticamente desestimula a própria pesquisa.

A SBPC é uma ferrenha lutadora pela criação das Fundações de Apoio à Pesquisa e Inovação e, com a 66a reunião anual que acontecerá em Rio Branco, agora em julho [2014], estaremos mais atentos a isso. Com as eleições para presidente e governadores que se aproximam, esta reunião anual será um importante espaço para que pesquisadores da região amazônica possam cobrar propostas concretas para o desenvolvimento da ciência e tecnologia em todo o país e, principalmente, na região, com uma séria política de divulgação científica.

Publicado no jornal A Tarde, Salvador, em 19 de junho de 2014.

\section{Jovens cientistas criadores de cultura}

"Física também é cultura" foi o título da tese de doutorado do meu mestre, professor João Zanetic, do Instituto de Física da USP, por volta de 1990. Aqui pela Bahia, outra querida referência acadêmica, o saudoso professor Felippe Serpa, também insistia que o ensino das ciências tinha que superar o "conteudismo" das fórmulas prontas e avançar para uma formação científica ampla da juventude. Além disso, pensava na não separação da ciência com a cultura e ia mais longe: defendia sempre que ambas tinham que ser vistas no plural, ou seja, as ciências e as culturas tinham que estar sempre articuladas.

Essas são questões que me vêm à mente, principalmente quando tanto se fala na mídia sobre os últimos resultados do Programa Internacio- 
nal de Avaliação de Estudantes (Pisa), recentemente divulgados. O Brasil ficou em $59^{\circ}$ lugar em ciências, em um ranking de 65 países. Gostando ou não das metodologias usadas nesses testes de ranking que comparam países, escolas e pessoas, o fato é que os alunos brasileiros não estão indo bem em matemática, leitura e ciências. E, lamentavelmente, não precisamos dos testes para isso constatar. Basta um olhar atento aos jovens para se observar uma escrita deficiente, pouca habilidade com os números e uma não familiaridade com fenômenos básicos da natureza.

Esse não é um problema fácil de ser enfrentado. Acabamos de ter aprovado no Senado o Plano Nacional de Educação, depois de uma tramitação de mais de dois anos. Entre as tantas emendas, acrescentou-se mais uma meta - fazendo com o projeto retorne à Câmara dos Deputados - que trata da produção científica brasileira, dando ênfase à pesquisa, desenvolvimento e estímulo à inovação.

A formação de professores e a melhoria das aulas de ciências são aspectos importantes, porém, não bastam. Precisamos de políticas públicas que articulem diversas áreas, especialmente educação, cultura, ciência e tecnologia, visando a implantação de museus, planetários, bibliotecas, hackers labs, fab labs, espaços coletivos, abertos e inspiradores para que a meninada possa construir e criar intensamente, numa forte articulação com as culturas e com as escolas.

A questão fundamental é não se limitar a formação científica apenas à dimensão escolarizada, ou seja, não basta que a juventude tenha mais e melhores aulas de ciências. Os conteúdos formais são importantes, mas não podem ser "repassados" de forma descontextualizada. É necessário fazer com que os jovens tenham gosto pelos fenômenos da natureza e pela criação - e não apenas pelo consumo de informação científica - contribuindo, dessa forma, com a melhoria das próprias aulas de ciências, que passam a ter outros significados.

Além disso, é urgente que esses jovens compreendam que, para tal, não são necessárias pessoas especiais, vindas de outros países ou planetas, mas que essas descobertas são parte da criação realizada por nós 
mesmos, os/as jovens brasileiros de todas as classes sociais e que tenham à sua disposição um ecossistema pedagógico público fortalecido, composto por equipamentos públicos de qualidade e professores, também eles fortalecidos, atuando em todos esses espaços.

Publicado no jornal Correio* ${ }^{*}$, Salvador, em 23 de dezembro de 2013.

\section{Não matem o Museu de C\&T da Boca do Rio!}

Preparava-me para escrever aos três candidatos à Reitoria da Universidade do Estado da Bahia (UNEB), que estão em campanha na busca de obter apoio da comunidade para administrar a maior universidade multicampi do Estado, presente em 24 municípios baianos. Minha cobrança pública seria em relação ao destino do histórico Museu de Ciência e Tecnologia, cujo prédio na Boca do Rio está ocupado pelo setor de extensão da Universidade, tendo sido praticamente destruído o belo projeto liderado pelo então governador Roberto Santos. Cobrança esta já feita publicamente à Uneb aqui mesmo em $A$ Tarde, quando da outorga do título de doutor honoris causa ao presidente da Academia de Ciências da Bahia, ex-reitor e ex-governador Roberto Santos. Na oportunidade, todos mencionaram a criação do referido Museu como uma importante obra do homenageado sem, no entanto, pronunciar uma só palavra sobre a sua reconstrução.

No final do mês passado, pelo decreto estadual no 14.719, o Museu de Ciência e Tecnologia (MCT) foi transferido da Secretaria de Educação - portanto da UNEB - para a Secretaria de Ciência, Tecnologia e Inovação (SECTI), assim como foi para a SECTI o histórico Centro de Pesqui- 